\title{
Comparative evaluation of modified neem leaf, wood ash and neem leaf extracts for seed treatment and pest control in maize (Zea mays L.)
}

\author{
E. I. Moyin-Jesu*
}

Agronomy Department, Federal College of Agriculture, Akure, Ondo State, Nigeria

\begin{abstract}
An experiment was conducted at Akure, rainforest zone of Nigeria to evaluate the effectiveness of neem leaf, wood ash extracts, modified neem leaf extract, Apron star 42WS and Karate $720 \mathrm{EC}$ as seed treatment and pest control in maize. The organic treatment extracts namely neem leaf extract, wood ash extract applied at $1200 \mathrm{ml}$ per hectare and modified neem leaf extract (1:1 ratio $600 \mathrm{ml}$ wood ash $+600 \mathrm{ml}$ neem leaf extract) were compared with Apron star 42WS (seed treatment), Karate 720EC and control treatment (no neem leaf, wood ash extracts nor Karate), replicated four times and arranged in randomized complete block design. The results showed that there were significant differences $(\mathrm{P}<0.05)$ in the germination counts, insect population, number of damaged leaves, growth and yield parameters of maize under different treatments compared to the control treatment. The modified neem leaf extract performed better in germination counts, reduction of damaged leaves, insect population and yield of maize than the sole application of neem leaf and wood ash. For percentage germination counts, Apron star $42 \mathrm{WS}$ had $65 \%$ followed by modified neem leaf extract (57\%), wood ash extract (51\%), neem leaf extract $(47 \%)$ respectively. Modified neem leaf extract increased the leaf area, plant height and stem girth of maize by $8 \%, 5 \%$ and $7 \%$ respectively compared to the neem leaf (sole) extract. Generally, modified neem leaf extract had the best values of maize growth parameters followed by Karate, neem leaf and wood ash extracts respectively. Modified neem leaf extract decreased significantly the insect population, number of damaged leaves and number of holes per plant in maize by $33 \%$, $70 \%$ and $30 \%$ respectively compared to the neem leaf extract (sole). When compared to modified neem extract, Karate decreased the number of damaged leaves per sample plot by $33 \%$. However, there was no significant difference between karate and modified neem extract for insect population. For yield parameters, modified neem leaf extract significantly increased the maize yield gains by $15 \%, 14 \%$ and $2 \%$ compared to neem leaf, wood ash extracts and karate treatments respectively. However, wood ash and neem leaf extracts did not affect significantly the maize yield. Therefore, the modified neem leaf extract applied at $1200 \mathrm{~L} / \mathrm{ha}(3 \mathrm{~L} / 25 \mathrm{~m} 2)$ was most effective for pest control and seed treatment in maize crop.
\end{abstract}

Keywords: neem leaf, wood ash extract, modified neem leaf, pest control and maize.
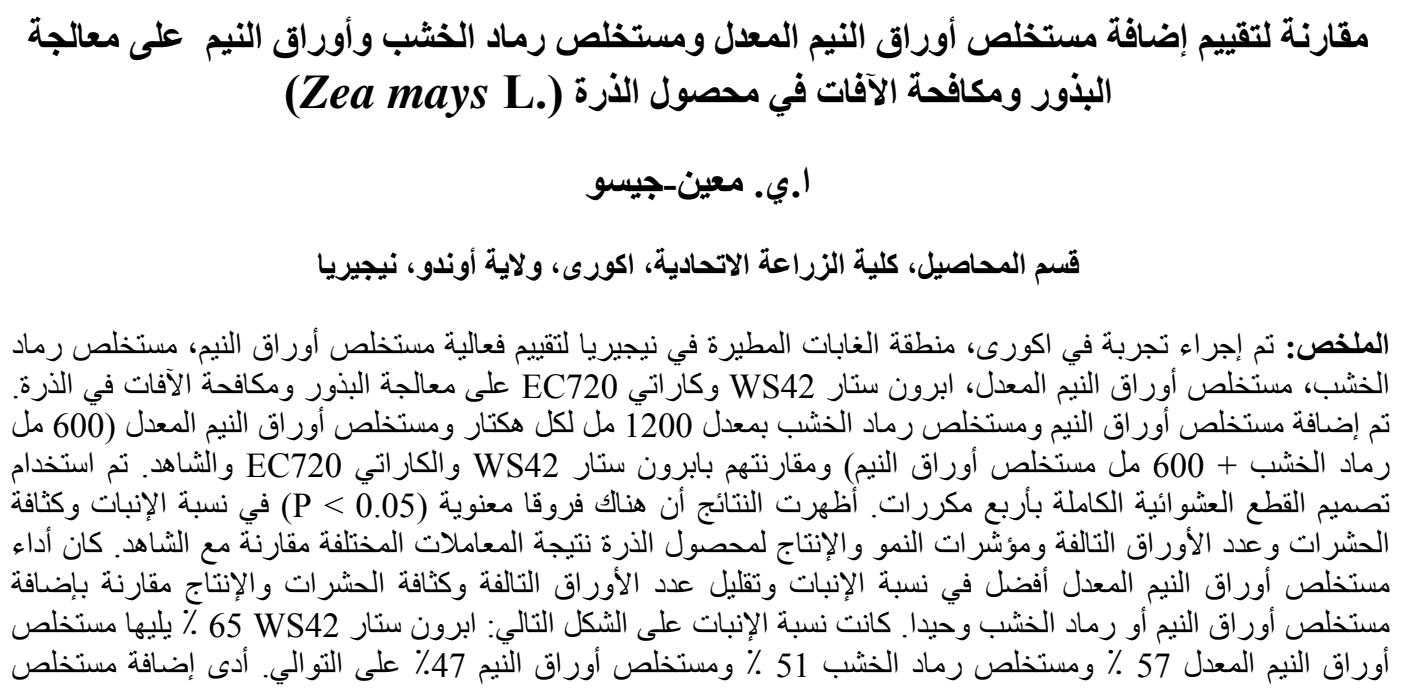

* Corresponding Author, Email: moyinjesu2004@yahoo.com 


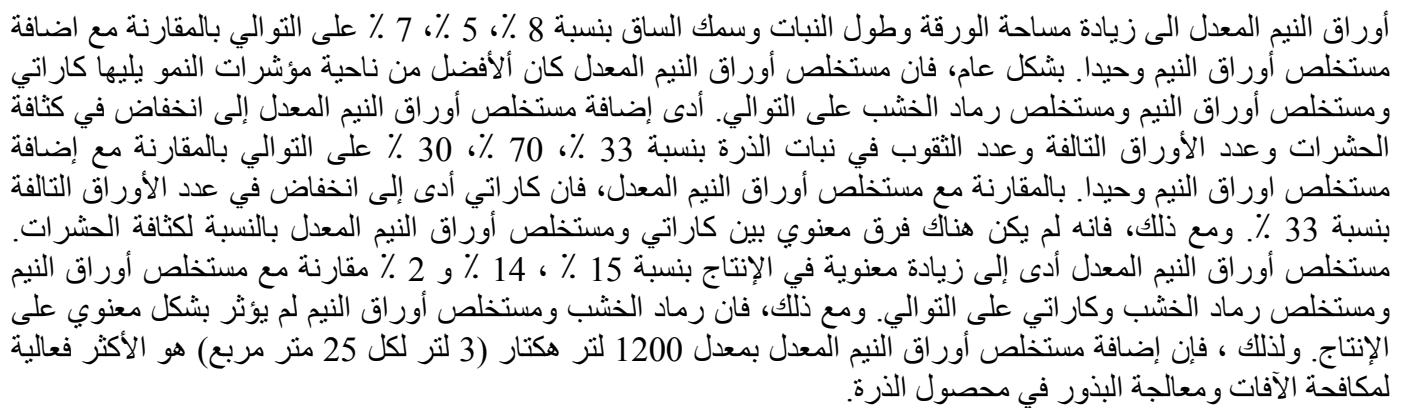

\section{Introduction}

Maize, Zea mays L. (Liliidae: Poaceae) is used as forage and in the manufacture of livestock feed, food stuffs, sweeteners, beverage and industrial alcohol, and oil (Du Plessis, 2003). Maize is widely grown worldwide with a total world production of approximately 1 billion metric tons. Average production per hectare worldwide is 3.5 metric tons per hectare and this varies considerable between countries of the world from 1.5 metric tons/hectare in Nigeria to 8.8 metric tons/hectare in the U.S. Among African countries, Nigeria is the leading maize producer with 27.5 million metric tons produced on 18.3 million hectares of land (USDA-FAS 2009).

An important factor in the lower production rate in Nigeria is the injury caused by pest before seedling emergence and during growth period. Bush fowl, lizards, crickets, rats and squirrels eat the sown maize seeds and caterpillars and armyworms feed on the growing maize plants. These problems discourage many small farmers from engaging in large scale maize production due to the increased cost of seeds. Pesticides are effective as seed treatments for maize and other vegetable crops (Alegbejo, 2001, Adesiyan, 1992) but in Nigeria the cost of pesticides are relatively high and the availability is low. Pesticides are also often associated with environmental pollution and health hazards (Iyagba, 2001).

Alternative treatments to pesticides are often derived from the neem tree,
Azadirachta indica L. (Sapindales: Meliaceae). Plant parts and extracts are used for insect repellants and biological insecticides (Odeyemi, 1984). Wood ash has insecticidal properties (Messiah, 1992, Famisa, 2004). The mixture of wood ash and neem leaf extract is referred to as modified neem leaf extract and there is a scarcity of research information on the efficacy of modified neem leaf extract.

The objective of the research reported herein was to identify alternative treatments to conventional pesticides, derived from the neem tree and/or wood ash, for maize seeds and growing maize plants. Specifically, (i) To determine the effectiveness of seed treatments with modified neem leaf extract, wood ash alone and neem leaf extract alone and compare these alternatives to standard pesticide seed treatments with fungicide, Apron Star 42WS (20\% thiamethoxam, $20 \%$ metalaxyl-M, 2\% difeconazole, Syngenta Crop Protection Co.) and an insecticide, Karate 720EC (lambdacyhalothrin, Syngenta Crop Protection Co.); and (ii) To determine the economic benefits/cost ratio of the use of modified neem leaf extract, wood ash and neem leaf extract in comparison to the standards.

\section{Materials and methods}

The experiment was conducted in Akure in the rain forest zone of Nigeria between 2004 and 2005. The annual rainfall is $1300 \mathrm{~mm}$ and temperature is $24.4^{\circ} \mathrm{C}$ while the relative humidity is $80 \%$. The soil is sandy loam, skeletal, kaolinitic, 
isohyperthermic belonging to Alfisol (Soil Survey Staff, 1999).

\section{Preparation of the neem leaf and wood ash extracts}

Five $\mathrm{kg}$ of fresh neem leaves were collected from 10 year old neem tree plantation, thoroughly cleaned from debris and other foreign materials, chopped with secateur into smaller pieces and put inside a 50L container filled with 40 litres of water placed under shade to allow easy leaching of the nutrients into the solution. The solution was stirred every three (3) days interval until 14 days when it is assumed that the nutrients would have been completely released leaves. Thereafter, the leaves were sieved out of the solution using $2 \mathrm{~mm}$ sieve and the extract was collected and stored in a clean container with a good lid ready for use. The concentrated solution was further diluted at ratio of 1:1 with water. Wood ash extract was prepared by dissolving $5 \mathrm{~kg}$ of sieved wood ash in 40 litres of water, stirred properly everyday for 7 days, filtered using clean white cloth and the extract collected was applied at $3 \mathrm{~L} / 25 \mathrm{~m}^{2}(1200 \mathrm{~L} / \mathrm{ha})$ for the control of pests. The modified neem leaf extract was prepared by mixing $600 \mathrm{~L}$ of concentrated neem leaf extract and 600 litres (L) of wood ash solution in a ratio $1: 1(1.5 \mathrm{~L}$ wood ash $/ 1.5 \mathrm{~L}$ neem leaf extract or $600 \mathrm{~L} / 600 \mathrm{~L}$ per ha respectively).

The Karate (720EC) insecticide solution (Lamba cyhalothrin) was prepared by measuring $2 \mathrm{ml}$ of karate EC into 10 litres of water and sprayed on maize seedlings at specified intervals for the control of pests. Apron star $42 \mathrm{WS}$ (20\% thiamethoxam, 20\% metalaxyl, 2\% difeconazole) was used as seed treatment for maize seeds and it is prepared by using one sachet of $10 \mathrm{~g}$ to treat $5 \mathrm{~kg}$ of maize seeds. Application of the neem leaf, wood ash and modified neem leaf extracts as seed treatments was carried out by soaking $5 \mathrm{~kg}$ of maize seeds in 5 litres of each treatment solution for 6 hours overnight prior to the planting date.

\section{Field Experiment}

The site was cleared, ploughed, harrowed and laid out into plots and each plot size is $5 \mathrm{~m} \mathrm{x} 5 \mathrm{~m}\left(25 \mathrm{~m}^{2}\right)$. There were six insecticidal treatments namely; neem leaf extracts applied at $\left(3 \mathrm{~L} / 25 \mathrm{~m}^{2} ; 1200 \mathrm{~L} / \mathrm{ha}\right)$, wood ash extracts $\left(3 \mathrm{~L} / 25 \mathrm{~m}^{2} ; 1200 \mathrm{~L} / \mathrm{ha}\right)$, modified neem leaf extract $(600 \mathrm{~L}$ wood ash $+600 \mathrm{~L}$ neem leaf extract) in a ratio $1: 1$, karate $(20 \mathrm{ml} / 20 \mathrm{~L}$ of water used as pest control, Apron star 42WS was used as seed treatment (1 sachet $10 \mathrm{~g}$ per $5 \mathrm{~kg}$ of maize seeds) and a control treatment (no leaf extract nor karate nor Apron star 42WS), replicated four times and arranged in a randomized complete block design. Two maize seeds (DMR) soaked in different solutions were planted at a spacing of $90 \times 30 \mathrm{~cm}$ and germinated after five days of planting. The percentage $(\%)$ germination of the maize seeds was determined and the values were recorded.

Weeding operation started at 2 weeks after planting and continued at 4, 6 and 9 weeks after planting. while the insecticidal treatments were applied twice at $2^{\text {nd }}$ and $6^{\text {th }}$ weeks after planting $\left(3 \mathrm{~L} / 25 \mathrm{~m}^{2}\right.$ or $1200 \mathrm{~L} / \mathrm{ha})$. The measurements for plant height $(\mathrm{cm})$, leaf area $\left(\mathrm{cm}^{2}\right)$ and stem girth (cm) were done weekly starting from 2 untill 6 weeks after planting while the data on number of insect pests per plant, number of hole per plant and identification of insect pests were taken starting from 2 weeks after planting till 10 weeks after planting at weekly interval using quadrant sampling on each plot. At 15 weeks after planting, maize cobs were harvested, dehusked dried, shelled and weighed for dry grains yield at $12 \%$ moisture content.

\section{Chemical analysis of the treatment solutions}

Five $\mathrm{ml}$ of each treatment solution was taken for laboratory analysis. The active 
ingredient content Azadirachitin for neem leaf was determined using atomic absorption spectrophotometer AOAC (1970). The $\mathrm{K}, \mathrm{Ca}$ and $\mathrm{Mg}$ contents of the treatment solutions were determined on flame photometer while the $\mathrm{P}$ content was developed into yellow coloration vanado molybdate reagent and read on spectrums 20. The active ingredient of wood ash $\mathrm{CaCO}_{3}$ was determined using flame photometer. AOAC (1970).

\section{Statistical analysis}

The data obtained from plant height, leaf area, stem girth, number of insects, number of damaged hole per plant and yield of maize plant under different treatments were analyzed by ANOVA F- test and their means were separated by Duncan Multiple Range Test at 5\% level. Data from germination counts of maize seeds were expressed in percentages and transformed before analysis using Arcsine transformation as described by Gomez and Gomez (1984).

\section{Results}

Germination counts of maize seeds under different seed treatment solutions

The data on the germination counts of maize seeds under different treatment solutions are presented in Table 1. There were significant increases $(\mathrm{P}<0.05)$ in the germination counts of maize seeds under different treatment solutions compared to control treatment. For instance, the use of neem leaf, wood ash extracts, modified neem leaf extract and Apron star 42 WS as seed treatment gave the maize germination percentage after 5 days of planting $47 \%, 51 \%$, $55.1 \%$ and $65 \%$ respectively compared to $44 \%$ of the control treatment (no neem leaf nor wood ash extracts nor Apron star $42 \mathrm{WS}$ ).

Modified neem leaf extract had maize germination count $55 \%$ compared to that of that of $47 \%$ and $51 \%$ for neem leaf and wood ash extracts respectively. The germination count percentage of maize seeds treated with Apron star 42 WS was $65 \%$ compared to neem leaf (47\%), wood ash extract $(51 \%)$ and modified neem leaf extract $(55.1 \%)$ respectively. The transformed data of percentage germination followed the same trend of performance.

Table 1. Germination count of maize after five days of planting under different seed treatment solutions.

\begin{tabular}{lllll}
\hline Treatments & \multicolumn{2}{l}{$\begin{array}{l}\text { Means germination Percentage } \\
(\%)\end{array}$} & $\begin{array}{l}\text { No. of seeds } \\
\text { planted }\end{array}$ & $\begin{array}{l}\text { No. of seed } \\
\text { germinated }\end{array}$ \\
\cline { 2 - 3 } & Untransformed & Transformed & & \\
\hline Control & $44.2 \mathrm{a}$ & $41.67 \mathrm{a}$ & 138 & $61 \mathrm{a}$ \\
Neem leaf extract & $46.9 \mathrm{~b}$ & $43.22 \mathrm{~b}$ & 138 & $65 \mathrm{~b}$ \\
Wood ash extract & $51 \mathrm{c}$ & $45.57 \mathrm{c}$ & 138 & $70 \mathrm{c}$ \\
Modified neem leaf & $55.1 \mathrm{~d}$ & $47.93 \mathrm{~d}$ & 138 & $76 \mathrm{~d}$ \\
extract & & & & \\
Apron star 42WS & $65.4 \mathrm{e}$ & $53.97 \mathrm{e}$ & 138 & $90 \mathrm{e}$ \\
\hline
\end{tabular}

Treatment means followed by the same letters are not significantly different from each other using Duncan Multiple Range Test (DMRT) at 5\% level. 


\section{Chemical composition and insecticidal properties of the treatment solutions}

Table 2 presents the data on the chemical composition and insecticidal properties of the treatments used for seed treatment and pest control in maize Modified neem leaf extract had the highest values of $\% \mathrm{M}, \mathrm{P}, \mathrm{K}, \mathrm{Ca} \mathrm{Mg}$ compared to wood ash and neem leaf extracts (sole forms) respectively Generally, the sole form of neem leaf had better values of $\% \mathrm{~N}$ and $\mathrm{P}$ than wood ash. Wood ash extract had higher values of $\% \mathrm{~K}, \mathrm{Ca}$ and $\mathrm{Mg}$ than neem leaf.

Table 2. Chemical composition of the treatment solution and their insecticidal properties.

\begin{tabular}{|c|c|c|c|c|c|c|c|c|c|}
\hline \multirow[t]{2}{*}{ Treatments } & \multirow[t]{2}{*}{$\mathbf{N}$} & \multirow[t]{2}{*}{$\mathbf{P}$} & \multirow{2}{*}{$\begin{array}{r}\mathbf{K} \\
\mathbf{0}\end{array}$} & \multirow[t]{2}{*}{ Ca } & \multirow[t]{2}{*}{ Mg } & \multirow{2}{*}{$\begin{array}{l}\text { Functional } \\
\text { group name }\end{array}$} & \multirow[t]{2}{*}{ Class } & \multicolumn{2}{|c|}{ Quantity Applied } \\
\hline & & & & & & & & $/$ plot & /hectare \\
\hline $\begin{array}{l}\text { Jeem leaf } \\
\text { xtract }\end{array}$ & $3 . \overline{56}$ & 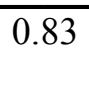 & $\overline{1.67}$ & $\overline{0.77}$ & 0.75 & Azadirachitin & $\begin{array}{l}\text { Tetra } \\
\text { notriterpenoid }\end{array}$ & $3 \mathrm{~L} / 25 \mathrm{~m}^{2}$ & $1200 \mathrm{~L}$ \\
\hline $\begin{array}{l}\text { Wood ash } \\
\text { extract }\end{array}$ & 0.15 & 0.53 & 2.60 & 15.00 & 1.00 & Calcium carbonate & & $3 \mathrm{~L} / 25 \mathrm{~m}^{2}$ & $1200 \mathrm{~L}$ \\
\hline $\begin{array}{l}\text { Modified } \\
\text { neem leaf }\end{array}$ & 3.69 & 1.10 & 3.2 & 15.66 & 1.53 & $\begin{array}{l}\text { Azadirachitin } \\
+ \text { Calcium carbonate }\end{array}$ & $\begin{array}{l}\text { Tetra } \\
\text { enotriterpenoid }\end{array}$ & $\begin{array}{l}3 \mathrm{~L} / 25 \mathrm{~m}^{2} \\
3 \mathrm{~L} / 25 \mathrm{~m}^{2}\end{array}$ & $\begin{array}{c}600 \mathrm{~L}+ \\
600 \mathrm{~L} \\
=1200 \mathrm{~L}\end{array}$ \\
\hline +Karate $720 \mathrm{EC}$ & & - & - & - & - & Lamba Cyhalothrin & & $\begin{array}{r}20 \mathrm{ml} / 10 \mathrm{~L} \\
/ \mathrm{plo}\end{array}$ & of water \\
\hline $\begin{array}{l}\text { +Apron Star } \\
42 \mathrm{WS} \\
\text { (seed treatment) }\end{array}$ & - & - & - & - & - & $\begin{array}{l}20 \% \text { thiamethoxam } \\
20 \% \text { metalaxyl } \\
2 \% \text { difeconazole }\end{array}$ & & $\begin{array}{r}10 \mathrm{~g} \text { sachet } \\
\text { maiz }\end{array}$ & per $5 \mathrm{~kg}$ \\
\hline
\end{tabular}

The karate 720EC and Apron star 42 WS did not have any component of N, P, $\mathrm{K}, \mathrm{Ca}$ and $\mathrm{Mg}$. The functional groups responsible for insecticidal properties of neem leaf extract are Azadirachtin and calcium carbonate in wood ash extract respectively while those in karate $720 \mathrm{EC}$ is Lamba cyhalothrin and the combination of $20 \%$ thiamethoxam, $20 \%$ metalaxyl and $2 \%$ difeconazole in Apron star $42 \mathrm{WS}$ used as seed treatment. Apron star $42 \mathrm{WS}$ has dual use of being fungicide and seed treatment.

\section{Growth parameters of maize under different treatment solutions}

There were significant increases $(\mathrm{P}<0.05)$ in the leaf area, plant height and stem girth of maize plants under the different treatment solutions of neem leaf wood ash, modified neem leaf and karate compared to the control treatment (Table $3)$.

Modified neem leaf extract (neem leaf +wood ash extracts) increased the leaf area, plant height and stem girth of maize by $8 \%, 5 \%$ and $7 \%$ respectively compared to neem leaf (sole) extract. It also increased the same parameters by $5 \%, 2 \%$ and $10 \%$ respectively compared to wood ash extract.

Generally, modified neem leaf extract had the best values of growth parameters followed by karate, neem leaf and wood ash extract respectively. When compared to karate, modified neem leaf extract increased the leaf area and plant height by $1 \%$ and $19 \%$ respectively. 
Table 3. Mean values of growth parameters of maize between 3-6 weeks after planting under different treatment solutions.

\begin{tabular}{llll}
\hline Treatments & Leaf area $\left(\mathbf{c m}^{2}\right)$ & Plant Height $(\mathbf{c m})$ & Stem girth $(\mathbf{c m}$ \\
\hline Control & $370.52 \mathrm{a}$ & $78.70 \mathrm{a}$ & $3.6 \mathrm{a}$ \\
Neem leaf extract & $481.51 \mathrm{~b}$ & $116.75 \mathrm{c}$ & $6.36 \mathrm{c}$ \\
Wood ash extract & $497.68 \mathrm{c}$ & $119.78 \mathrm{~d}$ & $6.10 \mathrm{~b}$ \\
Modified neem leaf extract & $523.25 \mathrm{e}$ & $122.21 \mathrm{e}$ & $6.82 \mathrm{~d}$ \\
Karate 720 EC & $520.25 \mathrm{~d}$ & $98.77 \mathrm{~b}$ & $6.98 \mathrm{e}$ \\
\hline
\end{tabular}

Treatment means followed by the same letters are not significantly different from each other using Duncan Multiple Range Test (DMRT) at 5\% level.

\section{Effect of insect infestation on the maize plants under different treatment solutions}

The data on the effect of insect infestation on the maize plants under different treatment extracts are presented in table 4. There were significant decreases $(\mathrm{P}<0.05)$ in the insect population per plant, number of damaged leaves and number of holes per plant under the neem leaf, wood ash, modified neem leaf extracts and karate compared to the control treatment.

Modified neem leaf extracts decreased the insect population, number of damaged leaves and numbers of holes per plant in maize by $33 \%, 70 \%$ and $30 \%$ respectively compared to the neem leaf extract (sole).
Karate also decreased significantly the number of damaged leaves per plot by $33 \%$ respectively compared to the modified neem leaf extract. However, there was no significant decrease in the insect population between modified neem leaf extract and Karate as marginal decrease of $9.5 \%$ was observed.

Among the treatment extracts, modified neem leaf was the most effective in reducing insect population, number of damaged leaves and number of holes per plant followed by both wood ash and neem leaf extract respectively. The high number of pests (eleven) under the control treatment had caused economic injury level for the maize plants compared to the treatment extracts.

Table 4. Effect of insect infestation on the maize plants under different pest control treatment solutions.

\begin{tabular}{llll}
\hline Treatments & $\begin{array}{l}\text { Insect population } \\
\text { per plant }\end{array}$ & $\begin{array}{l}\text { Number of } \\
\text { damaged leaves }\end{array}$ & $\begin{array}{l}\text { Number of holes } \\
\text { per plant }\end{array}$ \\
\hline Control & $11 \mathrm{c}$ & $34.0 \mathrm{e}$ & $84.56 \mathrm{e}$ \\
Neem leaf extract & $2.8 \mathrm{~b}$ & $16.56 \mathrm{~d}$ & $44.56 \mathrm{c}$ \\
Wood ash extract & $3.2 \mathrm{~b}$ & $15.56 \mathrm{c}$ & $47.12 \mathrm{~d}$ \\
Modified neem leaf extract & $2.0 \mathrm{a}$ & $10.18 \mathrm{~b}$ & $31.50 \mathrm{~b}$ \\
Karate 720 EC & $1.81 \mathrm{a}$ & $6.81 \mathrm{a}$ & $14.25 \mathrm{a}$ \\
\hline
\end{tabular}

Treatment means followed by the same letters are not significantly different from each other using Duncan Multiple Range Test (DMRT) at 5\% level.

\section{Yield parameters of maize under different treatment extracts}

There were significant increases $(\mathrm{P}<0.05)$ in the weight of maize grains $(\mathrm{kg} / \mathrm{ha})$ under different treatment extracts compared to the control treatment (Table 5). Modified neem leaf extract (wood ash + neem leaf extracts) increased the maize grains by $15 \%$ and $14 \%$ compared to neem leaf and wood ash extracts respectively. It also increased maize grains yield by $2 \%$ compared to karate treatment.

Generally, among the treatment extracts, modified neem leaf extract had the best values of maize grains yield followed by Karate while the wood ash and neem leaf extract did not differ significantly in maize yield. 
Emir. J. Food Agric. 2010. 22 (1): 37-45

http://ffa.uaeu.ac.ae/ejfa.shtml

Table 5. Yield parameters of maize plants under different pest control treatment solutions.

\begin{tabular}{ll}
\hline Treatments & Weight of grains (kg/ha) \\
\hline Control & $1028 \mathrm{a}$ \\
Neem leaf extract & $1868 \mathrm{~b}$ \\
Wood ash extract & $1888 \mathrm{~b}$ \\
Modified neem leaf extract & $2188 \mathrm{~d}$ \\
Karate 720 EC & $2048 \mathrm{c}$ \\
\hline
\end{tabular}

Treatment means followed by the same letters are not significantly different from each other using Duncan Multiple Range Test (DMRT) at 5\% level.

\section{Discussion}

Among the organic treatment solutions used, modified neem leaf extract (neem leaf + wood ash extracts) gave the highest germination count in maize indicating that it was the most effective as seed treatment. This was because its composition was made of both the neem leaf and wood ash solution extracts which possess insecticidal active ingredients (Azadirachitin and calcium carbonate) that protect maize seeds from attack of pests such as termites, rodents lizards, land squirrels and birds before and after seedling emergence. Besides, the neem leaf extract had bitter taste which made it impossible for rodents, land squirrels and birds to pick the seeds while the wood ash extract imparted a greyish colour on the maize seeds which changed the yellow colour to greyish colour which made it difficult for the birds to recognize such seeds either on the ground or from the air. This observation was supported by Das and Karim (1968) who reported that increasing concentration of neem and wood ash extract was effective in preventing birds attack on planted seeds of maize.

The highest germination counts in maize seeds under Apron star 42WS treatment indicated that it was the most effective as seed treatment for maize. This could be due to high degree of effectiveness of its active ingredient $(20 \%$ thiamethoxam $20 \%$ metalaxyl-M and $2 \%$ difeconazole) over that of azadirachitin in neem leaf and calcium carbonate in wood ash extracts. However, its continuous use may increase the concentration of the active ingredient in soils causing environmental pollution to the ecosystem compared to the modified neem leaf solution which has little residual effect on the environment, cheaper and gives a positive result.

This observation was supported by Idoni (1997) who reported that increasing concentration of neem extract above 80 grammes / 10litres of water was as effective as using Apron star 42WS (i.e. chemical).

The increase in maize growth parameters such as leaf area, plant height and stem girth under neem leaf extract indicated that its use favoured the growth of maize by decreasing insect population, number of damaged leaves and number of holes. This could be as a result of the neem leaf active ingredient (azadirachitin) which repelled insect attack that could have impaired the normal growth activities in maize.

This observation was supported by Odeyemi (1984) who reported that the leaf or kernel of neem tree has a morality effect of about $30 \%$ on Callosobrunchus maculata, beetles and whiteflies on the field.

In-addition, the performance of the growth parameters of maize under wood ash extract confirmed that it was effective as pest control treatment as noticed in the reduced insect population, number of leaves damaged and number of holes. This observation was supported by Ayoade (1977), and Messiah (1992) who reported the effectiveness of insecticidal property of wood ash in controlling pests of rice and okra which encouraged their 
photosynthetic capability and subsequently good growth and yield of the two crops.

One interesting observation was that the soaking of the maize seeds in wood ash extract changed the yellow colour of maize to greyish colour. This has blurred the vision of the birds and mammals from picking the planted seeds. In-addition the maize seedlings will have time to grow effectively without suffering the initial attack of seedlings by bush fowl, lizards, birds and so forth. In-fact, this is a great advantage in using wood ash extract as both seed treatment and pest control treatment.

The least values of insect population, number of damaged leaves and number of holes under the modified neem leaf extract compared to sole forms of neem leaf extract and wood ash extract proved that it was most effective as control treatment against grasshoppers, caterpillars, bettles and wire worms in maize. This explained the fact that it had the highest value of maize yield.

Furthermore, this could explain the fact that it had the least economic threshold level and the implication is that the maize plants will grow and produce good yield. This assertion was supported by Ivbijaro (1983) who reported that application of $3 \mathrm{~g}$ of ground neem seeds extract on cowpea seedlings reduced damage by various insects.

The highest number of pests and reduced yield in maize plants under the control treatment might be responsible for the increased damage of foliar parts which led to high economic injury level in the maize plants. This could be due to non application of neither neem leaf extract nor wood ash extract, therefore, the more a farmer ignores the use of insecticidal solution on his/her farm, the more the farm is exposed to high pest infestation.

Besides, the balanced nutrient composition of neem leaf, wood ash and modified neem leaf extracts especially \% $\mathrm{N}, \mathrm{P}, \mathrm{K}, \mathrm{Ca}$ and $\mathrm{Mg}$ would have also added to the nutrient supply of maize plant and aided their growth parameters and yield of maize, although this was not measured as part of the experiment. However, this is an advantage for these solutions besides their uses as both seed treatment and pest control simultaneously in the experiment. There is no specific agrochemical, karate or Apron star 42WS which can be used as both seed treatment and pest control as well as supplying nutrients to soils.

\section{Conclusion and recommendation}

It is concluded that the use of organic insecticidal solutions such as neem leaf, wood ash and modified neem leaf extracts were effective in reducing insect population and number of damaged leaves in maize, increased the maize yield and treatment solutions for germination of maize seeds.

Therefore, it is recommended that the application of modified neem leaf extract applied at $3 \mathrm{~L} / 25 \mathrm{~m}^{2}(1200 \mathrm{~L} / \mathrm{ha})$ was effective for pest control and seed treatment in maize crop. This is against the backdrop that karate and Apron star 42WS agrochemicals were very expensive and their continuous use might pollute the environment.

\section{References}

Adesiyan, S. O. 1992. Chemical control of nematode pests of some economic crops. In: Proc. $1^{\text {st }}$ Regional Symposium on biology and control of nematode pests of food crops in Africa. B. Fawole, O. A. Ogunjobi, J. O. Babatola and A. A., Idowu (Eds.), University of Ibadan, July 26-29, 1992: 283-294.

Alegbejo, M. D. 2001. Reaction of okra cultivars screened for resistance to okra masaic virus in Samaru, Northern Guinea Savanna, Nigeria. J. Sust Agric. Environ. 3:315-320. 
AOAC. 1970. Official Methods of Analysis $12^{\text {th }}$ ed. AOAC, Arlington, VA.

Ayoade, F. C. 1977. Insecticide spray schedule evaluation of pests. Nigeria J. Plant Protection 3:129-136.

Das, W. C. and H. Z. Karim. 1968. Use of wood ash as surface protectant. Tropical grain legume bulletin. No. 33-32.

Du Plessis Jéan. 2003. Maize production. South Africa Department of Agriculture, Resources Centre Directorate Agriculrtural Information Services. Private Bag X144, Pretoria, 0001 South Africa. 38 p. Online: www.nda.agric.Za/publications.

Famisa, A. O. 2004. Evaluation of different levels of wood ash solution as insecticide on the pests infestation and maize yield. HND Project work Agronomy Department, Federal College of Agriculture, Akure, Nigeria. 26-35.

Gomez A. I. and A. A. Gomez. 1984. Statistical procedures for agricultural research. Second edition. John Wiley and Son. New York.

Idoni, P. O. 1997. Effectiveness of neem seed as an insecticide on cowpea yield. HND Project work Agronomy Department, Federal College of Agriculture, Akure, Nigeria. 25-30.

Ivibijaro, M. F. 1983. Preservation of cowpea with neem seeds. Fuss Protect. Ecol. 5:127-182.

Iyagba, A. G. 2001. Chemical weed and pest control in a cassava/okra intercrop. A paper presented at the $19^{\text {th }}$ Annual Conference of Horticultural Society of Nigeria. University of
Nigeria, Nsukka, Nigeria: 6-8. May 28-June 1, 2001.

Messiah, M. C. 1992. Evaluation of insecticides of plant origin. J. Plant Protect. 2:1-83.

Odeyemi, S. Y. 1984. Laboratory evaluation of neem leaf toxicity on cowpea beetle (Callosobronchus maculate). Res. Bulletin No. 45:453483.

Soil Survey Staff. 1999. Soil Taxonomy. A basic system for soil classification for making and interpreting soil surveys. Agric. Handbook No. 436, USDA, Washington, D.C.

USDA-FAS 2009. World Agricultural Production. United State Department of Agriculture Foreign Agricultural Services Circular Series W November 2009AP 11-09. Online: http://www.fas.usda.Gov/psdonline/ circulars/production.pdf. 